\title{
EKSPLORASI PERSEPSI REMAJA TENTANG SEKS PRANIKAH PADA REMAJA DI KECAMATAN KEMA KABUPATEN MINAHASA UTARA
}

\author{
Lumentah M.Prisca $^{1}$, Indriani Yauri ${ }^{2}$, Asnet Leo Bunga ${ }^{3}$ \\ 1,2 Ilmu Keperawatan, Fakultas Keperawatan Universitas Katolik De La Salle Manado, \\ Kairagi 1 Kombos Manado, Sulawesi Utara 95000; ${ }^{3}$ STIK St. Carolus Jakarta \\ E-mail: priscalumentah15@gmail.com
}

\begin{abstract}
Abstrak
Latar Belakang: Persepsi remaja tentang seks pranikah dapat mempengaruhi tindakan remaja terhadap seks pranikah. Seks pranikah akan menimbulkan beberapa dampak kesehatan maupun sosial. Tingginya angka kejadian seks pranikah di Indonesia sehingga dianggap perlu untuk mengeksplorasi persepsi remaja tentang seks pranikah.

Metode Penelitian: Metode penelitian ini menggunakan desain deskriptif kualitatif. Penelitian deskriptif kualitatif didasarkan pada fenomena empiris, manusia sebagai alat, menggunakan pengetahuan intuisi, deskripstif berupa kata-kata tertulis atau lisan dan bukan diperoleh dengan prosedur statistik. 12 remaja (6 Laki-Laki dan 6 Perempuan) telah berpartisipasi dalam penelitian ini yang didapat melalui teknik convenience sampling dan data dikumpulkan melalui metode Focus Group Discussion. Teori Health Belief Model mendukung analisis persepsi remaja tentang seks pranikah.

Hasil penelitian: Lima tema yang dihasilkan yaitu, pengetahuan tentang seks pranikah, dorongan melakukan seks pranikah, dampak sosial sebelum dan sesudah, perubahan fisik sekarang dan nanti dan Upaya coping remaja. Sesuai dengan konseptualisasi teori Health Belief Model bahwa ketika ada kerentanan dan bahaya dari seks pranikah dapat dimotivasi melalui pengalaman orang lain, diri sendiri dan media sosial yang didukung oleh adanya keuntungan dan kerugian dari tindakan pencegahan seks pranikah, maka remaja akan mempercayai dan melakukan tindakakan berdasarkan dengan kepercayaannya tentang seks pranikah.

Kesimpulan: Hasil dari penelitian ini menunjukkan bahwa kemungkinan untuk melakukan tindakan pencegahan pada seks pranikah dipengaruhi oleh keyakinan dan kepercayaan remaja pada seks pranikah. Maka penelitian ini dapat menjadi bahan masukkan pada PUSKESMAS sebagai pengembangan materi-materi edukasi yang sesuai dengan konteks lokal untuk menunjang progam Pelayanan Kesehatan Peduli Remaja (PKPR), sebagai edukasi bagi orang tua bahkan remaja dan dapat menjadi bahan pengembagan untuk penelitian selanjutnya.
\end{abstract}

Kata kunci : Persepsi Remaja, Seks pranikah

Kepustakaan : 18 Buku (Tahun 2009-2016), 6 E-Book, 34 Jurnal, dan 6 Internet File 


\section{PENDAHULUAN}

Budaya seks pranikah di negara barat sangat berbeda dengan Budaya Indonesia. Menurut Christina (2010) menyebutkan bahwa hubungan seksual diluar perkawinan adalah hubungan yang wajar terjadi, yang biasa dilakukan oleh dua orang dewasa sebagai pemilik tubuh yang sama-sama suka. Sedangkan menurut Anna (2011) Budaya di negara barat tentang seks pranikah sangatlah berbeda dengan Negara-negara di Asia. Di Indonesia terdapat norma-norma yang melarang seseorang melakukan hubungan seks pranikah sebelum adanya ikatan perkawinan. Dengan demikian terdapat perbedaan budaya di negara barat dan di Indonesia tentang perilaku seks pranikah.

Perilaku seks bebas akan menimbulkan beberapa dampak pada remaja. Menurut Kementrian Kesehatan RI (2011), hubungan seksual yang dilakukan remaja yang belum menikah akan menimbulkan beberapa dampak diantaranya Kehamilan Tidak Diinginkan (KTD) yang umumnya dapat berujung pada tindakan Aborsi, kemudian beresiko untuk mengalami Penyakit Menurlar Seksual (PMS). Jika remaja telah melakukan hubungan seks prenikah ada kecendrungan untuk berganti-ganti pasangan, dan hal tersebut dapat berdampak terjangkitnya penyakit HIV/AIDS (Human Immunodeficiency Virus/ Acquired Immunodeficiency Syndrome) (Kethy,2014). Dengan demikian agar supaya remaja tidak mengalami dampak dari seks pranikah, remaja perlu dibekali dengan pendidikan seks sedini mungkin.

Seks pranikah dapat menimbulkan beberapa dampak diantaranya Penyakit Menular Seksual dan tindakan aborsi. Menurut data dari KemenKes RI tahun 2015, angka penderita Penyakit Menular Seksual (PMS) pada remaja terdapat 7.335 kasus, sedangkan angka kehamilan remaja diIndonesia mencapai 480 dari 1000 kehamilan, dan kehamilan pada remaja ini dapat berdampak pada tindakan aborsi, di Indonesia tindakan aborsi dilakukan oleh dua juta wanita setiap tahun, dan 70.000 wanita diantaranya dilakukan oleh remaja putri yang belum menikah.

Seks pra-nikah pada remaja telah menjadi masalah di seluruh dunia. Hal tersebut dapat dibuktikan oleh World Health Organization (WHO) yang menyebutkan bahwa 25\% Remaja berumur 15-19 tahun telah melakukan seks pra-nikah di negara-negara maju seperti Amerika Serikat, Inggris dan Australia (WHO,2013). Menurut penelitian yang dilakukan secara nasional di Cina tahun 2011 bahwa 22,4\% remaja pernah melakukan hubungan seks pranikah, di Taiwan 22\% telah melakukan hubungan seks pranikah tanpa menggunakan kondom (Chiao dan Yi CC, 2011). Menurut servei dari Komisi Perlindungan Anak Indonesia (KPAI) dan Kementrian Kesehatan RI pada Oktober 2013 menunjukkan sebanyak $43 \%$ remaja sudah melakukan seks pranikah dengan kekasihnya (KemenKes RI,2013)

Di Provinsi Sulawesi Utara masih terdapat banyak kasus seks pra-nikah di kalangan remaja. Hal ini di dukung oleh penyataan Kepala Sub Bidang Bina Kesehatan Remaja BKKBN Verry Laurens di website BKKBN (2015) yang mengungkapkan bahwa sesuai servei sepanjang tahun 2014 dari 11 Kabupaten Kota tercatat 524 remaja hamil karena melakukan hubungan seks pranikah atau $35,01 \%$ dari jumlah remaja di Sulawesi Utara. Sedangkan di Desa Kema I Minahasa Utara melalui Pusat Kesehatan Masyarakat (PUSKESMAS) Kema, terdapat 19 orang remaja yang sedang mengandung, dan menurut data kujungan ibu hamil di Poli KIA (Kesehatan Ibu dan Anak) tahun 2016, terdapat 40 remaja datang ke PUSKESMAS untuk memeriksakan kehamilan mereka.

Berbagai usaha dan upaya telah dilakukan untuk menekan angka kejadian seks pra- 
nikah. Diantaranya usaha yang dilakukan oleh WHO (2010) di beberapa negara maju dan negara berkembang telah menerapkan program "Health strategy for women's, children's, and adolescent's health" yaitu dengan penyuluhan kesehatan, pelayanan kesehatan reproduksi dan Keluarga Berencana (KB), dan meningkatkan penggunaan alat kontrasepsi pada remaja yang mengalami kehamilan tidak diinginkan. Sedangkan diIndonesia sendiri melalui Kementrian Kesehatan RI (2011) mempunyai Program Pelayanan Kesehatan Peduli Remaja (PKPR), sedangkan melalui website BKKBN (2010) mempunyai program Penyiapan Kehidupan Berkeluarga bagi Remaja (PKBR).

Melalui pemasalahan tersebut peneliti merasa perlu untuk mengadakan eksplorasi tentang persepsi remaja tentang hubungan seks pra-nikah. Hasil dari studi ini memberikan gambaran tentang factor-faktor yang mendorongan atau motif remaja melakukan tindakan seks.

\section{METODE PENELITIAN}

Penelitian ini adalah penelitian deskriptif kualitatif. Penelitian ini didasarkan pada fenomena empiris dan bersifat alamiah. Manusia sebagai alat dan menggunakan pengetahuan intuisi, deskripstif berupa katakata tertulis atau lisan dan bukan diperoleh dengan prosedur statistik (Sugiyono, 2014). Dalam proses pengumpulan data menggunakan Focus Group Discussion (FGD).

Penelitian ini dilaksanakan di Desa Kema I dan Desa Lilang yang merupakan wilayah kerja PUSKESMAS Kema Minahasa Utara pada bulan Juni 2017. Sampel dalam penelitian ini remaja yang berusia 15-18 tahun yang berjumlah 12 remaja yang terdiri dari 6 remaja laki-laki dan 6 remaja perempuan dengan menggunakan teknik convenience sampling. Untuk mendapatkan informan peneliti bekerja sama dengan tenaga kesehatan di Puskesmas dengan mengikuti kegiatan POSYANDU (Pos Pelayanan Terpadu) di Desa Kema I dan Desa Lilang dan meminta bantuan kader-kader untuk mengumpulkan remaja yang bersedia untuk menjadi informan.

Instrumen dalam penelitian ini yaitu Peneliti sendiri, 6 pertanyaan penuntun, alat perekam suara dan alat tulis menulis. Penelitian ini menggunakan teknik validias konfirmabilitas atau peneliti melakukan konfirmasi kembali pada informan untuk menyamakan pendapat antara peneliti dan dan informan .Proses menganalisis data hasil penelitian ini menggunakan analisis data tematik, ketiga peneliti terlibat dalam proses menganalisis data, sehingga tema yang muncul telah disepakati bersama. Untuk memenuhi kode etik penelitian, para informan diberi informasi yang cukup tentang manfaat dan dampak dari penelitian ini. Informan juga di beri kebebasan untuk berpartisipasi atau tidak berpartisipasi sehingga keikut sertaannya adalah bersifat sukarela. Mereka juga diinformasikan bahwa data yang diperoleh akan dijaga kerahasiaannya (confidenciality) oleh sebab itu identitas informan akan disamarkan (Anonomity). Seluruh informan menandatangani informed consent sebelum pengumpulan datadilakukan.

\section{HASIL PENELITIAN}

Dari hasil penelitian dan analisis data menggunakan analisis tematik maka didapatlah lima tema yaitu: 1) Pengetahuan tentang seks pranikah, dengan kategori: Yang saya ketahui tentang seks pranikah dan Tindakan yang mengarah ke seks pranikah 2) Dorongan melakukan seks pranikah, dengan kategori: perilaku teman terhadap seks pranikah, keteladanan orang tua dan situs porno mudah diakses melalui media sosial 3) Dampak sosial sebelum dan sesudah, dengan kategori: pemenuhan ekonomi yang mendesak dan ketidaksiapan menghadapi 
perubahan sosial 4) Perubahan fisik sebelum dan sesudah, dengan kategori: resiko penyakit menular, ketidaksiapan menghadapi perubahan sosial 5) Upaya Coping, dengan kategori: seks pranikah menimbulkan depresi dan Berdoa dan meningkatkan iman kepada Tuhan penting dalam upaya pencegahan seks pranikah.

\section{Pengetahuan tentang seks pranikah}

Dari hasil penelitian, dapat digambarkan pemahaman tentang seks pranikah adalah bersetubuh atau berhubungan suami istri, melakukan aktivitas seks diluar nikah, dan merupakan seks yang melanggar hukum, sehingga ini menjadi sebuah Pengetahuan tentang seks pranikah. Salah satu contoh komentar remaja seperti: "kalo menurut kita seks pranikah itu seks yang dilakukan sebelum menikah kong so bersetubuh lakilaki deng perempuan" ( P 1) (Kalau menurut saya seks pranikah itu seks yang dilakukan sebelum adanya ikatan pernikahan tetapi sudah melakukan hubungan bersetubuh antara laki-laki dan perempuan).

\section{Dorongan melakukan seks pranikah}

Berdasarkan penelitian dan analisis data yang telah dilakukan, Tema Dorongan melakukan seks pranikah bisa berasal dari teman sebaya, orang tua dan sosial media. Contoh komentar sebagai berikut: "misalnya dorang pe orang tua so nda ja urus di rumah, kong bergaul deng orang-orang nda betul akhirnya terjerumus. Mungkin dari broken home ato karna ada masalah keluarga" (L 1). (Misalnya orang tua mereka sudah tidak memperhatikan mereka dirumah, kemudian mereka salah dalam memilih pergaulan akhirnya dia terjerumus dalam pergaulan bebas. Mungkin dari broken home atau ada masalah keluarga)"tu situs-situs porno dorang so gampang ja buka kong bauni” (L 6)(Situs-situs porno sekarang mudah untuk diakses dan langsung ditonton).

\section{Dampak sosial sebelum dan sesudah}

Dari hasil penelitian yang telah dilakukan tema Dampak sosial sebelum dan sesudah didapat dari Perekonomian rendah dengan pergaulan kelas atas, menggunakan alat kontrasepsi untuk menunda kehamilan, menanggung malu karena hamil diluar nikah yang dapat mengakibatkan depresi yang dapat berujung pada tindakan aborsi. Seorang remaja berkomentar: "kalo cewe toh kong dia miskin bagitu kong depe tamang bergaul tu orang-orang kaya otomatis dia suka bagaja le sama deng dorang jadi dia putar otak noh deng pigi deng om-om supaya dapa doi for mo bagaya sama deng depe tamang"(P 2). (kalau perempuan miskin dan mempunyai pergaulan di kalangan katas, otomatis ia harus menyesuaikan kehidupannya dengan teman-temannya akhirnya ia pun pergi dengan om-om untuk mendpatkan uang untuk memenuhi kebutuhannya).

\section{Perubahan fisik sekarang dan nanti}

Dari hasil penelitian dan analisis data yang telah dilakukan, tema Perubahan fisik sekarang dan nanti ini dapat dari: Dampak dari seks pranikah yaitu terkena Penyakit Menular Seksual dan kehilangan keperawanan dan keperjakaan yang dapat berdampak pada masa depan. Kata remaja tersebut sebagai berikut: “doh kalo so gantiganti pasangan sudah HIV AIDS dia" "panyaki langsung mo dola pa dia itu, nda mo jao-jao HIV AIDS so menunggu”(P 1) (kalau berganti-ganti pasangan maka akan mendapat penyakit HIV/AIDS sudah menunggu) Kemudian "ilang perawan, depe contoh eso-eso torang so ilang perawan deng laki-laki laeng kong jadi deng torang pe laki baru paling dorang mo ba pandang enteng akang” (P 3)(kehilangan keperawanan, contohnya nanti jika kita menikah dengan laki-laki yang berbeda maka nanti adanya sifat meremehkan kita) 


\section{Upaya Coping}

Bedasarkan hasil penelitian dan analisis data yang telah dilakukan tema Upaca Coping didapat dari dampak psikologis dari seks pranikah, dan upaya pencegahan yang remaja lakukan untuk mencegah seks pranikah. Diantara mereka mengatakan sebagai berikut:

"menurut kita musti memperkuat iman kase kuat iman pa Tuhan dengan cara baibadah, supaya nda mo ta goda, kalo so dekat deng tuhan pasti kuat tahan godaan" (P 6) (menurut saya kita harus memperkuat iman kita pada Tuhan dengan cara beribadah, supaya kita tahan akan godaan).

\section{PEMBAHASAN}

\section{Pengetahuan tentang seks pranikah}

Pengetahuan tentang seks pranikah dapat disimpulkan sebagai tindakan melakukan hubungan suami istri yang dilakukan tanpa adanya ikatan pernikahan, yang dapat dimulai dari berpacaran, kemudian berciuman, necking, sampai melakukan hubungan suami istri. Menurut Eka \& Heriana (2012) Seks pranikah adalah hubungan seksual yang dilakukan seseorang tanpa adanya ikatan pernikahan. Dengan demikian pengetahuan remaja tentang seks pranikah adalah hubungan seks tanpa adanya ikatan pernikahan. Menurut Koes (2014) Pengetahuan individu tentang kesehatan reproduksi yang meliputi cara merawat dan menjaga organ reproduksi beserta informasi yang tidak akurat yang dapat menimbulkan dampak dan pola perilaku seks yang tidak sehat dan membahayakan bagi seseorang. Hasil penelitian ini didukung oleh beberapa penelitian, diantaranya: Penelitian dari Yuli Farida (2013) yang menyatakan bahwa terdapat hubungan antara pengetahuan dengan perilaku seksual remaja, rendahnya pengetahuan tentang kesehatan reproduksi merupakan salah satu faktor yang mempengaruhi terjadinya hubungan seksual pra nikah pada re maja. Dan hal tersebut di dukung oleh Teori Health Belief Model, bahwa pengetahuan remaja tentang seks pranikah dapat berupa kerentanan dan bahaya dari seks pranikah yang dapat mempengaruhi tindakan/perilaku remaja terhadap seks pranikah.

\section{Dorongan melakukan seks pranikah}

Perilaku teman terhadap sekspranikah, Keteladanan orang tua, dan Situs porno mudah diakses melalui media sosial. Dorongan melakukan seks pranikah dapat dipengaruhi oleh pergaulan atau teman sebaya, dan hal tersebut dapat disebabkan oleh orang tua dalam hal ini Broken Home atau dari masalah dalam keluarga dan hal tersebut diatas tidak terlepas dari pengaruh media sosial yang dapat mendorong remaja melakukan tindakan seks pranikah. Koes (2014) adanya tekanan dari teman sebaya dan pacar seperti pengaruh buruk dari teman, dan seseorang cenderung mengikuti perilaku buruk yang dilakukan temannya, yang ditambah dengan rasa penasaran dan pelampiasan diri terhadap permasalahan dalam hidupnya. menurut Kathy (2013) Komunikasi antara anak dan orangtua haruslah berjalan dalam dua arah, agar supaya orang tua dapat menjadi sahabat dan tempat berlindung bagi anak remajanya, namun jika masalah yang ada pada orang tua dan keluarga membuat komunikasi antara orang tua dan anak memburuk, anak akan mencari tempat perlindungan yang baru dan dapat membawa anak tersebut pada pergaulan bebas. Dan hal tersebut didukung oleh teori Health Belief Model bahwa pengaruh atau saran dari orang lain dapat dan media massa dapat mempengaruhi persepsi remaja tentang seks pranikah yang dapat berpengaruh pada pengambilan keputusan untuk melakukan tindakan atau berperilaku seks pranikah.

\section{Dampak sosial sebelum dan sesudah}

Pemenuhan ekonomi yang mendesak dan Ketidaksiapan menghadapi perubahan sosial. 
Dampak sosial sebelum dan sesudah dapat dipengaruhi oleh tingkat ekonomi yang rendah (miskin) dan memiliki pergaulan yang tinggi (kaya), maka remaja dapat diperhadapkan dengan melakukan tindakan seks pranikah untuk dibayar, dan untuk menunda kehamilan remaja menggunakan pil KB dan kondom, namun jika pada akhirnya remaja tersebut hamil, remaja tersebut akan malu dan susah menyesuaikan diri dengan lingkungan sekitar. Penelitian dari Wulandari \& Sarwititi (2014) menunjukkan bahwa terdapat pengaruh antara status ekonomi keluarga dengan motif menikah dini pada remaja, bahwa penurunan status ekonomi keluarga maka akan menaikkan rata-rata motif menikah dini pada remaja untuk menaikkan status ekonomi keluarga. Kethy (2013) Faktor ekonomi temasuk faktor paling kuat atas terjadinya beberapa peristiwa yang bisa dikatakan melenceng dari norma-norma yang ada di masyarakat termasuk seks pranikah, dalam status ekonomi yang rendah dapat membuat seseorang melakukan apa saja untuk mendapatkan uang. Hasil penelitian tentang Ketidaksiapan menghadapi perubahan sosial di dukung oleh teori-teori Menurut (Sri, 2015) dampak dari seks pranikah adalah kejadian Kehamilan Tidak Diinginkan (KTD) yang akan berdampak pada kehidupan sosialnya, akan menanggung malu dan susah untuk menyesuaikan diri dengan orang lain. Dan hal tersebut didukung oleh teori Health Belief Model, bahwa terdapat keuntungan dan kerugian melakukan tindakan pencegahan. Maka perubahan perilaku haruslah diterapkan dalam hal ini adalah melakukan tindakan pencegahan, agar supaya tidak akan merakan kerugian atau dampak dari seks pranikah.

\section{Perubahan fisik sekarang dan nanti}

Resiko penyakit menular, ketidaksiapan menghadapi perubahan sosial. Perubahan fisik sekarang dan nanti dari seks pranikah adalah kehilangan keperawanan dan keperjakaan yang dapat merusak masa depan remaja tersebut dan beberapa dari mereka terkena Penyakit Menular Seksual karena kecenderungan mengganti-ganti pasangan. Hasil penelitian ini didukung oleh jurnal penelitian, yaitu: Penelitian dari Mardiana (2013) yang menunjukkan bahwa lebih dari $50 \%$ responden mempunyai gaya hidup yang negatif atau memicu terjadinya penyakit menular seksual, yaitu gaya menganggantiganti pasangan dalam berhubungan intim tanpa menggunakan kondom dan kurang dalam merawat kebersihan genetalia. Jadi kecenderungan mengganti-ganti pasangan dapat mengakibatkan Penyakit Menular Seksual. Menurut Fadjri (2014) \& KemenKes (2011) Dampak seksual beresiko antara lain yaitu kejadian Penyakit Menular Seksual (PMS) seperti Sifilis, Gonore/kecing nanah, Kandidosis vaginalis, HIV/AIDS, dan sebagainya. Kemudian Hery \& Metti (2014) seks pranikah dapat merusak masa depan, karena telah kehilangan keperawanan dan keperjakaan kebanyakan remaja tersebut sudah tidak bisa mewujudkan cita-citanya. Dan hal tersebut didukung oleh teori Health Belief Model, bahwa motivasi yang berasal dari pengalaman orang lain, diri sendiri dan saran dari tenaga medis dapat mempengaruhi persepsi remaja tentang seks pranikah.

\section{Upaya Coping}

Seks pranikah menimbulkan depresi dan Berdoa dan meningkatkan iman kepada Tuhan penting dalam upaya pencegahan seks pranikah. Dampak dari seks pranikah dapat menyebabkan remaja tersebut depresi yang akhirnya akan membawa remaja tersebut pada tindakan aborsi dan bunuh diri, maka dari itu remaja harus melakukan tindakan pencegahan seperti mendekatkan diri kepada Tuhan dan mengikuti kegiatan-kegiatan positif. Menurut Taufan (2014) mengemukakan bahwa upaya pencegahan seks pranikah adalah dengan mengikuti kegiatan-kegiatan positif dan berdoa kepada Tuhan. Menurut Koes (2014) peran orang tua 
dalam hal ini komunikasi sangat diperlukan dalam tindakan pencegahan perilaku seks bebas. Dengan demikian selain mendekatkan diri dengan Tuhan, perlu dukungan dari orang tua dan teman sebaya untuk mengadakan tindakan pencegahan seks pranikah. Dan hat tersebut didukung oleh teori Health Belief Model, bahwa ketika remaja tersebut mengetahui tentang keuntungan dan dari melakukan tindakan pencegahan, maka remaja tidak akan melakukan tindakan seks pranikah.

\section{KESIMPULAN}

Berdasarkan hasil penelitian ditemukan lima tema meliputi, Pengetahuan tentang seks pranikah, dorongan melakukan seks pranikah, dampak sosial sebelum dan sesudah melakukan seks pranikah, Perubahan fisik sekarang dan nanti dan Upaya coping remaja.

Persepsi remaja tentang seks pranikah dapat dipengaruhi oleh pergaulan, teman sebaya, media sosial dan hal tersebut dapat disebabkan oleh pengaruh dari orang tua/keluarga dan faktor ekonomi dan akan menyebabkan dampak sosial dan perubahan fisik pada remaja tersebut. Dan hal tersebut didukung dengan teori Health Belief Model yang mengatakan bahwa ketika ada kerentanan dan bahaya dari seks pranikah yang dapat dimotivasi melalui pengalaman orang lain, media sosial dan didukung oleh adanya keuntungan dan kerugian dari tindakan pencegahan dari seks pranikah, maka remaja akan berpendapat atau mempercayai dan melakukan tindakakan berdasarkan dengan kepercayaannya terhadap perilaku seks pranikah. Keterbatasan dari penelitian ini adalah peneliti hanya mengambil informan berusia mulai dari 1518 tahun atau usia Sekolah Menengah Atas.

\section{SARAN}

- Program Kesehatan Peduli Remaja (PKPR) terutama tentang kesehatan reproduksi, perlu ditingkatkan supaya dapat menjangkau remaja-remaja yang ada. Hal ini perlu dilakukan agar mereka tidak melakukan seks pranikah dan dapat melakukan tindakan pencegahan.

- Bagi remaja agar dapat memilih pergaulan dan teman yang baik, dan menggunakan masa muda sebaik mungkin, dengan mengikuti kegiatan-kegiatan positif yang ada, karena masa remaja akan menentukan masa depan. Bagi orang tua agar dapat membangun komunikasi yang baik dengan anak remaja, dan menjadikan anak remaja sebagai teman agar remaja akan memiliki sifat terbuka pada orang tuannya.

- Bagi peneliti selanjutnya agar dapat melakukan penelitian lebih lanjut dengan mengambil responden semua kategori umur mulai dari remaja awal, remaja menengah dan remaja akhir dan kemudian bandingkan persepsi disetiap kategori umur dan melanjutkannya pada jenis penelitian kuantitatif karena penelitian ini bisa menjadi sumber pengembangan kuisioner.

\section{DAFTAR PUSTAKA}

Anna, S. (2011). Perilaku seks pranikah dikalangan remaja. Jurnal Kesehatan.

BKKBN. (2010). PKKBR. Retrieved from Badan Kependudukan dan Keluarga Berencana Nasional: http://www/bkkbn.go.id/PKBR BKKBN. (2013). Seks Bebas pada remaja. Retrieved from Badan Kependudukan dan Keluarga Berencana Nasional: http://sulut.bkkbn.go.id/ViewArtikel.a spx?ArtikelID $=57$

Christina, S. (2010). Representasi sosial: Seksualitas, Kesehatatan, dan Identitas. Yogyakarta: Universitas Sanata Dharma.

Eka \& Herina, D. (2012). Memahami perkembagan fisik remaja. Yogyakarta: Gosyen Publishing. 
Fajri, K. (2014). Dampak perilaku seks beresiko terhadap kesehatan dan upaya penanganan. Jurnal studi pemuda.

Farida, Y. (2013). Hubungan pengetahuan dengan perilaku seksual remaja di SMU Negeri Kabupaten Karawang. Jurnal Keperawatan.

Hery, E. \&. (2014). Kesehatan Ibu dan Bayi pada Pernikahan dini. Jurnal Kesehatan.

Kathy, F. (2013). Kesehatan Seksual. Jakarta: Bimu Medika.

Kementrian Kesehatan, R. (2013). Situasi Kesehatan Reproduksi Remaja. Pusat data \& informasi Kesehatan RI.

Koes, I. (2014). Seksologi Kesehatan. Bandung: ALFABETA.

Mardiana. (2013). Gaya hidup remaja yang memicu terjadinya penyakit menular seksual di SMK Angkasa Mojosari Mojokerto. Artikel Jurnal.

Sarwititi, W. (2014). Pengaruh status ekonomi keluarga terhadap motif menikah dini di pedesaan. Jurnal Kesehatan.

Sri.A.A. (2015). Persepsi remaja terhadap perilaku seksual pada mahasiswa kos di lingkungan Universitas Riau Pekan Baru Riau. Jurnal Psikologi.

Sugiyono. (2014). Metode Penelitian Pendidikan. Bandung: ALFABETA.

Taufan. (2014). Upaya pencegahan seks pranikah. Artikel junal.

WHO. (2013). Fact sheet. Retrieved from World Health Organization: http://www.who.int/mediacentre/facts heets/fs345/en/ 